\title{
An Analysis of Sport Managers' Work Stress Levels in Various Variables ${ }^{\mathrm{i}}$
}

\author{
Zühal Kılınç*, Nevzat Dinçer \\ School of Physical Education and Sports, Batman University, Turkey
}

Copyright $\bigcirc 2018$ by authors, all rights reserved. Authors agree that this article remains permanently open access under the terms of the Creative Commons Attribution License 4.0 International License

\begin{abstract}
This paper was conducted to measure the psychological and psychosomatic symptoms related with the sport managers' work stress in public sector and federations. In this research, total 185 sport managers including 31 sport managers from the Central Organization of Sport General Directorate, 113 sport managers from the provincial organization, 41 sport managers from the Independent Sport Federations were included. The relevant managers were applied the work stress scale developed by Houso and Rizzo (1972). According to the results of the research, as sport managers get older, the averages of work stress seem to increase. In younger sport managers, the averages of work stress were found to be lower. When the participant sport managers' education levels improve, their work stress points fall down. In the first period of service of sport managers, the averages of work stress were high, in next years they went down over time.
\end{abstract}

\section{Keywords Stress, Work Stress, Sport, Manager}

\section{Introduction}

When a few people come together to reach a certain aim in collaboration in each part of society, management occurs. There is no human not being included in such a movement in society. That's why, each citizen exists in a social organization. These organizations are instruments which are arranged for other aims [1]. In fact, management has become an issue of many sciences since management is a social case, it involves all members of society, it is also identified with the concept of state [2].

Introduction of public goods and services provided to society by countries shows itself in various fields. One of these fields is youth services and sport [3]. Sport management requires utilising current human and material resources effectively and efficiently at most in order to succeed in certain sportive services [4]. Organizations make investments for their workers as their most valuable assets in order to survive within competition conditions rapidly increasing each passing day. Achievements or failures of organizations are absolutely directly-related with workers' stress-free moments. Therefore, it is necessary to analyze workers in an organization in which they mostly spend their lives and to reveal organizational stress factors. If any necessary importance is not given to organizational stress, it will lead to workers' dissatisfaction with works [5].

It is important to know the differences between what stress is and what factors cause stress. Various pressures, attitudes and demands from families, workplaces, schools, friends, and states are external stress resources. An individual's own pressures and expectations are internal stress resources as well. Internal stress resources are ambition, materializm, competition and obstinacy. Mostly internal stress resources are much more effective than external stress resources. All external and internal pressures, expectations are stress resources. Any reaction of a body to pressures from these resources represents stress. However nice it is or not, everybody knows that human body shows biochemical reactions to external requests. Even if stress resources are different, biological reactions do not vary in general [6].

Work stress poses a critical problem for both persons in any organization and any organization by itself. Work stress is an undesirable concept, which results in mental and physical diseases accompanied by physical stress resources related with work and inadequate struggle $[7,8,9$, $10,11]$. In addition to these, changing life conditions and increasing stress factors reveal that stress resources must be assessed in more global viewpoints [12]. Luthans classified stress resources in organizations in four groups. These are "organizational policies, structural features of organization, physical conditions and organizational processes". When organizations develop and attain a complex structure, stress resources triggering each other increase and organizations have difficulty in control [13].

Murphy (1995) researched the relation between work stress, personal characteristics and health, suggested that 
work stress may cause work dissatisfaction, depression, physical diseases and behavioral disorders [14, 15]. Furthermore, stress resources need to be analyzed in more actual viewpoints due to changing life conditions and increasing stress factors [12]. A research on work stress and workers' happiness indicates that there is a negative relation between manager, family support and depression, anxiety and physical symptoms [15].

Another research was carried out by Huang et al. (2002) and the effects of work stress on workers' health were studied [16]. Fairbrother and Warn (2003) discussed the relations between work health, stress, work satisfaction and work conditions [17]. Jamal (2005), focused on personal and organizational issues resulted from workers having work stress and behaviour features of A type [18].

Due to sport managers' professions, they experience stress in psychological, physical and mental ways in work environment. Their own stress is reflected on sport managers' work comrades, friends, family and social life negatively. Sport managers' own stress in work environment substantially affects the expectations of the institution and society. For this reason, minimising stress experienced by sport managers in work environment is important for making efficiency in managers' working institutions. The purpose of this research was to measure the psychological and psychosomatic symptoms related with the sport managers' work stress in public sector and federations. For that purpose, the following questions were replied;

1- At which levels the sport managers working at public sector and federations experience stress?

2- Do the stress levels of the sport managers working at public sector and federations differ in gender, age, educational background, period of service, management period, work unit and graduation department?

\section{Material and Method}

This is a descriptive study with screening model, which was conducted to measure psychological study and psychosomatic symptoms related with work stress in public sector and federations. The research group consisted of total 185 sport managers randomly chosen including 31 sport managers from the Central Organization of Sport General Directorate, 113 sport managers from the provincial organization, 41 sport managers from the Independent Sport Federations.

Data were collected with the Work Stress Scale developed by Houso and Rizzo (1972). The scale consisted of two sections, work stress scale demographical information in the first section, seven items related with work stress in the second section were presented. All items of the scale were pointed with the five point Likert type as 1: Certainly Agree, 2: Agree, 3: No Idea, 4: Disagree, 5: Certainly Disagree. The highest point from the scale was 35 , the lowest point was 7 as well. Since the interval width of the scale was estimated as "range width/relevant group number", in evaluating the relevant results, the mean ranges were considered as Certainly Agree (1.00-1.80), Agree (1.81-2.60), No Idea (2.61-3.40), Disagree (3.414.20), Certainly Disagree (4.21-5.00). The Cronbach Alpha reliability coefficient of the scale was estimated as .83 , because of this, the scale can be said to be highly reliable.

Data were analyzed with the SPSS 22.0 package program, resulting from the Kolmogorov Smirnov test applied for seeing whether data showed a normal distribution, the distribution was observed to be different rather than the normal distribution $(\mathrm{z}=0.14 ; \mathrm{p}<.05)$. In the analysis of data, non-parametric Mann Whitney- $U$ and Kruskall Wallis-H tests were used in the comparison of inter-groups data as well as the descriptive statistical techniques. The results were interpreted at the significance level of $\mathrm{p}<.05$ the level of significance was interpreted.

\section{Results}

In accordance with Table 1, of the sport managers $69,73 \%$ (129 persons) were males, 30,27\% (56 persons) were females. Half of the managers $(51,35 \%)$ was aged between $46-5,31,89 \%$ of them was aged between $6-45$, $14,05 \%$ was aged 56 and over. Most of the managers were graduates of bachelor degree $(61,62 \%), 25,41 \%$ of them was associate degree graduates, $12,98 \%$ was master graduates. When examined the period of service in the managers, most of them $(37,30 \%)$ had 26 years of service and over, $4,32 \%$ of them had $1-5$ years at least.

When also examined the management period of managers, half of them $(49,19 \%)$ had $1-10$ years of management period, the others had 11 years and over. $16,76 \%$ of the managers has been working at the Central Organization of Sport General Directorate, 22,16\% of them has been working at Independent Federations, 52,97\% at the Provincial Directorate, $8,11 \%$ a the District Directorate as well. When looked at the graduation department of the sport managers, most of them $(44,86 \%)$ graduated from İ̈BF. 
Table 1. The distributions of sport managers' demographical features

\begin{tabular}{|c|c|c|}
\hline Gender & $\mathbf{n}$ & $\%$ \\
\hline Male & 129 & 69,73 \\
\hline Female & 56 & 30,27 \\
\hline Age & $\mathbf{n}$ & $\%$ \\
\hline Aged 26-35 & 5 & 2,70 \\
\hline Aged 36-45 & 59 & 31,89 \\
\hline Aged 46-55 & 95 & 51,35 \\
\hline Aged 56 and over & 26 & 14,05 \\
\hline Educational Background & $\mathbf{n}$ & $\%$ \\
\hline Associate Degree & 47 & 25,41 \\
\hline Bachelor Degree & 114 & 61,62 \\
\hline Master Degree & 12 & 6,49 \\
\hline Doctorate & 12 & 6,49 \\
\hline Period of Service & $\mathbf{n}$ & $\%$ \\
\hline $1-5$ years & 8 & 4,32 \\
\hline $6-10$ years & 18 & 9,73 \\
\hline $11-15$ years & 28 & 15,14 \\
\hline $16-20$ years & 12 & 6,49 \\
\hline $21-25$ years & 50 & 27,03 \\
\hline 26 yıl ve üzeri & 69 & 37,30 \\
\hline Management Period & $\mathbf{n}$ & $\%$ \\
\hline $1-5$ years & 48 & 25,95 \\
\hline $6-10$ years & 43 & 23,24 \\
\hline $11-15$ years & 20 & 10,81 \\
\hline $16-20$ years & 27 & 14,59 \\
\hline $21-25$ years & 28 & 15,14 \\
\hline 26 years and over & 19 & 10,27 \\
\hline Work Unit & $\mathbf{n}$ & $\%$ \\
\hline Central Organization of Sport General Directorate & 31 & 16,76 \\
\hline Independent Federations & 41 & 22,16 \\
\hline Province Directorate & 98 & 52,97 \\
\hline District Directorate & 15 & 8,11 \\
\hline Graduation Department & $\mathbf{n}$ & $\%$ \\
\hline BESYO & 27 & 14,59 \\
\hline Education Faculty & 28 & 15,14 \\
\hline İIBF & 83 & 44,86 \\
\hline Other & 47 & 25,41 \\
\hline Total & 185 & 100,00 \\
\hline
\end{tabular}

In accordance with Table 2, by examining the general average of the sport managers' responses to the work stress scale $(2,62 \pm 1,07)$, the sport managers generally experienced stress. The managers mostly experienced stress by working in high tension $(2,49 \pm 1,50)$, even if they did other things at home, they often thought about their works, they could not decide whether they experienced stress. When looked at the averages of other stress-leading items in the managers, they were similar to each other. 
Table 2. The descriptive statistical results of scores from the work stress scale in sport managers

\begin{tabular}{lcc}
\hline Work Stress Items & Mean & Ss \\
\hline 1-My job affects my health directly. & 2,64 & 1,60 \\
2-I have been working under highly great tension. & 2,49 & 1,50 \\
3- I have been feeling angry by myself because of my job. & 2,56 & 1,51 \\
4-If I worked for a different job, my health possibly becomes better. & 2,51 & 1,42 \\
5-My job-related problems have caused my sleeping problems. & 2,52 & 1,57 \\
6- I have been feeling stressful before meetings at my workplace. & 2,58 & 1,46 \\
7-Even if I do other things at home, I have been always thinking about my job-related issues. & 3,04 & 1,47 \\
\hline Total & $\mathbf{2 , 6 2}$ & $\mathbf{1 , 0 7}$ \\
\hline
\end{tabular}

(1:Certainly Agree, 2: Agree, 3:No Idea, 4: Disagree, 5: Certainly Disagree)

Table 3. Mann Whitney U test results of the points from the work stress scale in managers in accordance with the gender variable

\begin{tabular}{ccccccccc}
\hline & Gender & N & Mean & Std. Dev. & Mean Rank & Total Rank & U & P \\
\hline \multirow{2}{*}{ Work Stress } & Male & 129 & 17,91 & 6,91 & 95,54 & 12324,50 & & \\
& Female & 56 & 17,00 & 7,59 & 87,15 & 4880,50 & 3284,500 & .32 \\
\hline
\end{tabular}

Any significant differences were not determined in the points from the work stress scale among the managers in accordance with the gender variable $(\mathrm{p}>.05)$.

Table 4. Kruskal Wallis-H test results of the points from the work stress scale in managers in accordance with the age variable

\begin{tabular}{ccccccc}
\hline Age & N & Mean & Std. Dev. & Mean Rank & Chi-Square & P \\
\hline Aged 26-35 & 5 & 14,80 & 4,02 & 70,60 & & \\
Aged 36-45 & 59 & 17,20 & 6,87 & 90,34 & & \\
Aged 46-55 & 95 & 18,20 & 7,61 & 96,26 & 1,402 & .70 \\
Aged 56 and over & 26 & 17,11 & 6,25 & 91,42 & \\
Total & 185 & 17,63 & 7,12 & & \\
\hline
\end{tabular}

Any significant differences were not found in the managers' work stress points in accordance with the age variable $(\mathrm{p}>.05)$.

At Table 5, there were not statistically significant differences in the sport managers' points from the work stress scale in terms of educational background $(\mathrm{p}>.05)$.

Table 5. Kruskal Wallis-H test results of the points from the work stress scale in managers in accordance with the educational background variable

\begin{tabular}{cccccc}
\hline $\begin{array}{l}\text { Educational } \\
\text { Background }\end{array}$ & $\mathbf{N}$ & Mean & Std. Dev. & Mean Rank & Chi-Square \\
\hline Associate & 47 & 16.19 & 6.36 & 79.28 \\
Bachelor & 114 & 18.84 & 7.88 & 98.42 & 5,692 \\
Master & 12 & 18.75 & 4.49 & 107.08 & .12 \\
Doctorate & 12 & 16.23 & 6.52 & & \\
Total & 185 & 17.97 & 7.31 & & \\
\hline
\end{tabular}

According to Table 6, the sport managers' points from the work stress scale significantly differed in period of service $(p<.05)$. As a result of Mann Whitney-U test which was done to determine which groups the differences resulted from, there were differences in favor of the group with 11-15 years of service between the group with 6-10 years of service and the group with 11-15 years of service $(U=142,000 ; z=-2,142 ; p<.05)$, in favor of the group with 26 years of service and over between the group with 6-10 years of service and the group with 26 years of service and over $(\mathrm{U}=300,500$; $\mathrm{z}=-2,726 ; \mathrm{p}<.05$ ), in favor of the group with 26 years of service and over between the group with 21-25 years of service and the group with 26 years of service and over $(U=1117,000 ; z=-2,486 ; p<.05)$. According to this result, when service period increases, sport managers' work stress levels reduce.

Table 6. Kruskal Wallis-H test results of the points from the work stress scale in managers in accordance with the period of service variable

\begin{tabular}{cccccc}
\hline Period of Service & N & Mean & Std. Dev. & Mean Rank & Chi-Square \\
\hline 1-5 years & 8 & 20,87 & 7,21 & 117,81 & \\
6-10 years & 18 & 21,00 & 7,25 & 116,78 & \\
11-15 years & 28 & 16,46 & 6,46 & 86,96 & 71,346 \\
16-20 years & 12 & 14,91 & 6,57 & 72,96 & 102,50 \\
21-25 years & 50 & 18,80 & 7,05 & 82,97 & \\
26 years and over & 69 & 16,49 & 7,13 & & \\
Total & 185 & 17,63 & 7,12 & & \\
\hline
\end{tabular}


At Table 7, the sport managers' points from the work stress scale did not significantly differ in management period $(\mathrm{p}<.05)$.

As a result of Mann Whitney-U test about whether which groups the differences related with management period resulted in, significant differences were seen in favour of the group with 11-15 years of management period between the group with 1-5 years of management period and the group with 11-15 years of management period $(\mathrm{U}=179,000 ; \mathrm{z}=-4,193 ; \mathrm{p}<.05)$, in favour of the group with $16-20$ years of management period between the group with $1-5$ years of management period and the group with 16-20 years of management period $(\mathrm{U}=323,500 ; z=-3,591 ; p<.05)$, in favour of the group with 26 years of management period and over between the group with 1-5 years of management period and the group with 26 years of management period and over $(\mathrm{U}=323,500$; $\mathrm{z}=-3,591 ; \mathrm{p}<.05)$, in favor of the group with $11-15$ years of management period between the group with 6-10 years of management period and the group with 11-15 years of management period $(\mathrm{U}=103,500 ; \mathrm{z}=-4,897 ; \mathrm{p}<.05)$, in favor of the group with 16-20 years of management period between the group with 6-10 years of management period and the group with 16-20 years of management period $(\mathrm{U}=227,000 ; \mathrm{z}=-4,205 ; \mathrm{p}<.05)$, in favor of the group with 21-25 years of management period between the group with 6-10 years of management period and the group with 21-25 years of management period $(U=414,000 ; z=-1,926$; $\mathrm{p}<.05$ ), in favor of the group with 26 years of management period and over between the group with 6-10 years of management period and the group with 26 years of management period and over $(\mathrm{U}=164,500 ; \mathrm{z}=-3,812$; $\mathrm{p}<.05$ ), in favor of the group with 26 years of management period and over between the group with 21-25 years of management period and the group with 26 years of management period and over ( $\mathrm{U}=126,000$; $\mathrm{z}=-2,796 ; \mathrm{p}<.05)$. According to this result, when management period increases, sport managers' work stress levels reduce.

At Table 8, there were not statistically significant differences in the sport managers' points from the work stress scale in terms of work unit ( $p>.05)$.

At Table 9, there were not significant differences in the sport managers' points from the work stress scale in terms of graduation department ( $p>.05)$.

Table 7. Kruskal Wallis-H test results of the points from the work stress scale in managers in accordance with the management period variable

\begin{tabular}{ccccccc}
\hline Management Period & $\mathbf{N}$ & Mean & Std. Dev. & Mean Rank & Chi-Square & P \\
\hline 1-5 years & 48 & 19,79 & 7,39 & 117,81 & & \\
6-10 years & 43 & 21,44 & 7,05 & 116,78 & & \\
11-15 years & 20 & 11,20 & 3,18 & 86,96 & & \\
16-20 years & 27 & 14,48 & 5,33 & 72,96 & 11,346 & \\
21-25 years & 28 & 18,10 & 5,62 & 102,50 & & \\
26 years and over & 19 & 14,15 & 6,23 & & \\
Total & 185 & 17,63 & 7,12 & & \\
\hline
\end{tabular}

${ }^{*} \mathrm{p}<.05$

Table 8. Kruskal Wallis-H test results of the points from the work stress scale in managers in accordance with the work unit variable

\begin{tabular}{cccccc}
\hline Work Unit & N & Mean & Std. Dev. & $\begin{array}{c}\text { Mean } \\
\text { Rank }\end{array}$ & Chi-Square \\
\hline SGM Central Organizations & 31 & 17,45 & 6,98 & 92,85 \\
Independent Federations & 41 & 18,78 & 6,50 & 105,12 & 3,435 \\
Province Directorate & 98 & 17,12 & 7,43 & 87,15 & .32 \\
District Directorate & 15 & 18,26 & 7,18 & 98,37 & \\
Total & 185 & 17,63 & 7,12 & & \\
\hline
\end{tabular}

Table 9. Kruskal Wallis-H test results of the points from the work stress scale in managers in accordance with the graduation department variable

\begin{tabular}{ccccccc}
\hline Graduation-Department & N & Mean & Std. Dev. & Mean Rank & Chi-Square & P \\
\hline BESYO & 27 & 18,62 & 7,36 & 99,50 & & \\
Faculty of Education & 28 & 20,25 & 6,92 & 115,29 & & \\
İ̈BF & 83 & 17,14 & 7,27 & 88,68 & 8,262 & .06 \\
Other & 47 & 16,38 & 6,54 & 83,62 & \\
Total & 185 & 17,63 & 7,12 & & \\
\hline
\end{tabular}




\section{Conclusions}

In this research which was done to reveal whether sport managers' work stress affected their social lives positively or negatively, these following results were obtained.

The sport managers working at the Central and Provincial Organizations of Youth and Sport General Directorate, the Independent Sport Federations were understood to have medium levels of work stress. Efeoğlu (2006) researched on workers in medicine sector and Tekgöz (2011) also researched on work stress, work satisfaction and life satisfaction levels of soccer referees, both of them found that the averages of work stress were at medium level $[19,20]$. Gökmen (2017) presented the average points of work stress as 2,54 for male participants as 2,48 for females among the public servants. These researches were parallel with our research results [21].

When looked at the points from the managers' work stress scale, any significant differences were not seen in terms of gender, age, educational background, work unit and graduation department variables. Efeoğlu (2006)'s research showed that demographical variables were not effective on work stress levels [19]. This result was parallel with our research. But the managers' period of service and management period variables significantly altered the managers' work stress levels [20]. Also, Tekgöz (2011) studied the relations between soccer referees' work stress, work satisfaction and life satisfaction levels, determined that soccer referees' work stress, work satisfaction and life satisfaction levels did not significantly differ in age, period of service, gender and educational background variables. Gökmen (2017) found that there were not any differences in work stress, work satisfaction including internal satisfaction and external satisfaction variables, age among public servants. This result was parallel with our research [21].

Torun and Tekin (2014), reported that there were not any significant differences between work stress of health institutions managers working in the province Ankara and age, gender, marital status, child number, marriage period, educational background and income status from personality features. However, there were significant differences in work stress levels between the sport managers' total service of period and management period within our research [22].

In conclusion, stress-leading factors must be determined and destroyed in order to turn the negative effects of work stress experienced in public institutions and organizations by the sport managers into the positive effects in social life. In particular, the sport managers must integrate some parts of their lives into sport in order to save themselves from work stress and so this will reduce their stress in work environment to some extent.

\section{REFERENCES}

[1] MORGAN, G. (1998) "Metaphor in Management and Organization Theories, Union of Türkiye Metal Industrialists Press, İstanbul.

[2] BAŞARAN, İ.E. (1984), "The Management of Employee Services in Organization", Faculty of Education Sciences Press, Ankara.

[3] IŞIKGÖZ, E. (2016). Managerial Efficiency of Provincial Directors in Youth Services and Sport. The Journal of Academic Social Science. 4, Vol. 31: 79-90.

[4] DOĞAR, Y (1997), "Sport Management in Turkey”, Öz Akdeniz Ofset, Malatya.

[5] AKGÜNDÜZ, S. (2006), "A Research on Effects of Organizational Stress Resources on Staff's Work Satisfaction and Banking Staff', Master Thesis, İzmir: Dokuz Eylül University, Social Sciences Institute.

[6] ÇiÇEK, C. G. (2006), "A Relation between Stress Levels and Work Satisfaction of Ship: Practice in Denizcilik Company", Master Thesis, Manisa: Celal Bayar University, Social Sciences Institute, Business Management Head of Department.

[7] LEONG, A.F. ve Cary L.C. (1996), "The Moderating Effect of Organizational Commitment on the Occupational Stress Outcome Relationship”, Human Relations, Vol 49, No:10.

[8] ARTAN, İ. (1987), "Organizational Stress Resources", Marmara University, İ.İ.B.F. Journal, Vol. IV, No 1-2.

[9] DUYMAZ, E. (1999), "Validity and Reliability of Managerial Stress Scale in Yönetici Hemşirelerde", Master Thesis, İzmir: Ege University, Health Sciences Institute.

[10] ÖZDEVECiOGLU, M. (2004), "Effects of Social Support and Life Satisfaction on Professional Stress: A Research on Active Business Owners in Kayseri”, H.Ü. İ. İ. B. F. Journal, Vol: 22, No: 1 .

[11] RAITANO, R. and KLEINER, B. (2004), "Stress Management: Stressors, Diganosis and Preventative Measures", Management Research News, Vol.24, No.4/5.

[12] KESER, A. (2014), "Work Stress Resources with Traditional and Current Dimensions. Ankara: Turkish Metal Press.

[13] GENÇ, N. (2004), "Management and Organization, Ankara: Seçkin Press.

[14] MURPHY, LAWRENCE R.(1995); “Managing Job Stress: An Employee's Assistance/Human Resource Management Partnership", Personnel 1 Review, Vol: 24, No: 1: 41-50.

[15] LU, LUO (1999); "Work Motivation, Job Stress and Employee's Well-Being", Journal of Applied Management Studies, Vol: 8, No:1: 61-73.

[16] HUANG, GRANT D. MICHAEL TEUERSTEIN, STEVEN L. SAUTER (2002); "Occupational Stress and Work-Related Upper Extremity Disorders: Concepts and Models", American Journal of Industrial Medicine, Vol: 41: 298-314.

[17] FAIRBROTHER, KERRY VE JAMES WARN, (2003), "Workplace Dimensions, Stress and Job Satisfaction", 
Journal of Managerial Psychology, Vol: 18, No: 1: 8-21.

[18] JAMAL, M. (2005), "Short Communication: Personal and Organizational Outcomes Related to Job Stress and Type-A Behavior: A Study of Canadian and Chinese Employees", Stress and Health, Vol: 21: 129-137.

[19] EFEOĞLU, İ. E. (2006), “The Effects of Work-Family Life Conflict on Work Stress, Work Satisfaction and Organizational Addiction: A Research in Medicine Sector", Adana: Çukurova University, Social Sciences Institute, Business Management Head of Department Doctorate Thesis.

[20] TEKGÖZ, Ü. (2011), Work Stress of Soccer Referees, Work Satisfaction and Life Satisfaction Levels: A Research on 3rd Region Coaches", Master Thesis, Kayseri: Erciyes University, Social Sciences Institute. Sport Management Head of Department.

[21] GÖKMEN, G. (2017), "Work Satisfaction in Public Staff, Emotional Labor and Work Stress: A Research in Konya", Bartın University, Social Sciences Institute, Business Management Head of Department, Master Thesis.

[22] TORUN, N. and TEKIN, P. Ș. , (2014); Evaluation of Work Stress and Personality Characteristics of Health Institutions Managers Working in Province Ankara, Ankara Health Services Journal, Vol: 13, No: 1.

\footnotetext{
${ }^{\text {i }}$ This article was held on 13-16 September 2018 in Gaziantep. It was developed from the declaration presented at the Zeugma International Congress of Multidisciplinary Studies.
} 